\title{
Exploring Facilitators and Challenges Facing ICT4D in Tanzania
}

\author{
Jim James Yonazi \\ Faculty of Computing, Information Systems, and Mathematics, the Institute of Finance Management, \\ Dar Es Salaam, Tanzania
}

\begin{abstract}
Successful implementation of Information and Communication Technology for development requires a sound understanding of the implementation-context. Interestingly, limited knowledge is available regarding issues potential to facilitate or challenge ICT4D implementation in developing countries. This study aims at establishing such issues in a framework of a developing country like Tanzania. A grounded approach was used for this study. The researcher establishes that, in the Tanzanian context, issues that facilitate ICT4D include affordability, availability of domesticable technologies, supportive social infrastructure and government commitment to ICT initiatives. The key challenges of ICT4D in the country include inadequate connectivity, inadequate content quality, unsupportive organisational issues and people-related issues. Accordingly, the researcher proposes a new view that shows challenges and facilitators are not static. The researcher argues that successful implementation of ICT4D in Tanzania is possible if issues established in this study are influenced in a continuum of adequacy from low to high. Thus, efforts need to be made to address the identified challenges, exploit and advancing facilitators and maintain them on the high-side of the continuum of adequacy.
\end{abstract}

Keywords: ICT, ICT4D, e-Government, Tanzania, Africa.

\section{Introduction}

Information and Communication Technology (ICT) for development (ICT4D) relates to the use of ICT in various social and economic activities (Kramer, Jenkins \& Kats, 2007). Currently, ICT is embedded in products and services we use and consume in our daily lives. As a result, it influences all aspects of development including social and industrial development (Cole \& Roman, 2003). Currently, various stakeholders including governments, international organisations, practitioners and civil societies appreciate and engage in advocating the utilisation of ICT in the development of the human race (Yusof \& Lim, 2003).

The role of ICT in social and economic development can have direct or indirect contributions. Direct contribution occurs when ICT is traded as a commodity. In this way, investments and profits-gains contribute directly to the economy. For instance, economic gains can be obtained when a country produces and trades ICT knowledge or products. This generates direct revenue to the economy of the country. Indirect contribution, on the other hand, arises when ICT is used to facilitate other social and economic development activities. Typical examples include the utilisation of ICT in health services, agriculture, education, governance and commerce sectors. According to Kramer, Jenkins and Kats (2007), ICT facilitates such activities by providing various advantages. Consider for instance when ICT results into reduction of transaction costs and thereby improves productivity or the case when ICT contributes to the provision

Copyright (C) 2012 Jim James Yonazi. This is an open access article distributed under the Creative Commons Attribution License unported 3.0, which permits unrestricted use, distribution, and reproduction in any medium, provided that original work is properly cited. Contact author: Jim James Yonazi E-mail: yonaz@ifm.ac.tz 
of immediate and low cost connectivity for digital multimedia. Further, the use of ICT can result in improving efficiency, transparency and accuracy, increasing choice in the market place and providing access to otherwise unavailable goods and services. The often advantageous use of ICT is when it results in widening the geographical scope of potential markets, and allowing knowledge and information sharing to the global community.

Although the application of ICT4D promises benefits towards achieving human development, it may also cause some negative aspects. For instance, Yusoff \& Lim (2003) posit that the application of ICT4D may accentuate social-economic inequalities amongst peoples and nations around the world. The United Nations reports (UN 2008, 2005) show that most of the Western countries have made significant progress in harnessing the benefits of ICT in their development. In contrast, most of the developing countries, particularly in Africa, still lag behind. As a result, the countries and the people therein experience social exclusion and dwindled human development. However, leapfrogging opportunities still exist if developing countries will intelligently exploit ICT for development (Ensley, 2005).

Successful implementation of ICT4D requires a sound understanding of the implementation context. Heeks (2005) argues that lack of adequate understanding of the context may result into designreality gap. Such a situation may limit the realisation of the expected benefits of deploying ICT4D. This may have severe consequences such as loss of money, time, trust and reputation. Accordingly, it is imperative to identify, understand and address issues that may influence successful implementation of ICT4D. Otherwise, little developmental benefits will be gained from ICT.

The literature presents various issues potential to influence successful implementation of ICT4D. These include inadequate human capital, inadequate technical infrastructure, literacy and financial capability, among others (Ensley, 2005; Hamelink, 1997, ITU, 2007, UN,
2008). The UN (2008) for instance, observes that such issues may include infrastructure, policies, capacity development, ICT applications, knowledge management and customer care practices, which determine any success in government ICT initiatives. The International Telecommunication Union (ITU) (2007) emphasises that access to ICT, high tariff costs, and the slow growth of an ICT industry have negatively influenced the implementation of ICT4D.

The issues presented in the literature have differing magnitude and importance in different contexts (Yonazi, 2010). Accordingly, successful implementation of ICT4D requires an informed decision making in the processes of designing, developing and deploying relevant initiatives in a particular context. This can be achieved by identifying contextual issues influencing the implementation process. Unfortunately, in the Tanzanian context, limited knowledge is available regarding contextual issues related to ICT4D implementation in the country. Accordingly, the purpose of this study is to contribute towards bridging this knowledge gap. This paper aims to establish issues that may facilitate or challenge successful implementation of ICT4D in the country. The researchers further provides a new view on such issues and recommend possible measures relevant for advancing ICT4D in Tanzania.

\section{ICT4D in Tanzania: An Overview}

Cognizant of the role of ICT in development, Tanzania has embarked on various ICT4D initiatives in the country. Typical examples include the implementation of various ICT initiatives in sectors such as the government, business, health and education (IICD, 2008; Sawe, 2007). Progress in ICT infrastructure improvement and local contents development has also been reported (Yonah, 2005). The government plans to streamline and implement more ICT4D initiates across the country (URT, 2003). The aim is to facilitate development activities in the country and boost socialeconomic growth (ibid). 
Although Tanzania is continuing to invest in ICT4D, the country is slow in making significant progress in ICT initiatives (UN, 2008). The UN reports that the country experiences inadequate application of ICT in its development priorities as stipulated in the National ICT Policy (UTR, 2003). This situation hampers the pace and direction of social and economic development in the country. Interestingly, few studies (e.g. Mutagayhwa, Kinyeki and Ulanga, 2007) have been conducted to assess the situation and provide relevant recommendations relevant to advance ICT4D implementation in Tanzania. The researcher has not come across a study which has dealt with facilitators and challenges of ICT4D in the country. This indicates that ICT4D practitioners in Tanzania are inadequately informed on how they can successfully implement ICT4D. Left unaddressed, this situation may lead to failure of ICT4D initiative in the country (Heeks, 2005). Accordingly, in this study the researcher aims at establishing key issues, potential to facilitate or challenge successful implementation of ICT4D in the country.

In this attempt, the researcher defines the facilitators as issues which currently provide a favourable environment for the successful application of ICT4D in a particular context. Understanding such issues informs ICT4D practitioners on factors that can be exploited or influenced when planning or evaluating ICT4D-related initiatives. The researcher termed such issue as facilitators of ICT4D. On the other hand, challenges refer to issues that need to be addressed; otherwise, they can potentially hinder successful implementation of ICT4D in Tanzania. The researcher termed such issue as challenges of ICT $4 D$.

\section{Methodology}

Several reasons were considered and influenced the researcher's choice on the fitting approach for this study. First, it is observed that the ICT4D concept is still new in Tanzania. Therefore, the actual meaning of what respondents and other data sources inferred needed to be interpreted rather than predetermined. Second, the researcher anticipated encountering data availability challenges especially from the government organizations. Third, the study was intended to identify issues typical to Tanzania. Accordingly, the researcher observed that the Grounded Theory Approach (GTA) was a fitting strategy for this study - GTA (Strauss and Corbin, 1990). In GTA, a researcher is facilitated to inductively derive meanings from data by systematically utilizing a set of procedures (Strauss and Corbin, 1990, p.24). In this study, this was achieved through open, focused, axial and selective coding of the data (ibid). This approach helped to explore the context and identify and interpret possible categories. This process was useful in highlighting relevant insights emerging from the data.

The researcher collected data from various sources. These include ICT practitioners, non-ICT practitioners and ordinary ICT users. The researcher also collected data through observation and analysed various documents. ICT practitioners provided this paper with insights of how ICT is being currently applied in development initiatives. They also informed on possible facilitators and challenges on implementing ICT initiatives in the country. Other sources provided the researcher with referential information concerning ICT4D in Tanzania.

Interviews, workshops and focus group discussions (FGDs) were used to collect opinions and experiences from both experts and users. Observations were made during researcher's site visits to Mwanza Municipal Council, Internet cafes in Dar es Salaam, Morogoro, and Zanzibar. The researcher also participated in a high level government meeting held at Utumishi office on 3rd March, 2009. Literature-based sources such as policies, reports and other recorded evidences were analysed at the beginning of the study and at the end of data collection. Interviews were useful for capturing personal accounts of the respondents, while FGDs were instrumental in revealing and discussing new issues and clarifying doubts. Literature- based sources were consulted to serve us with recorded and historical evidences. 
The researcher collected data from four regions in Tanzania; namely, Dar es Salaam, Morogoro, Mwanza and Zanzibar. Dar es Salaam was selected because it is the main business city of Tanzania. Morogoro and Mwanza were relevant sources to represent other regions in Tanzania with less business activities compared to Dar es Salaam. Zanzibar gave us information from the other side of the Union of the United Republic of Tanzania (URT).

The selection of potential respondents was done by first contacting professionals from the President's Office Public Services Management, Tanzania Global Development Learning Centre and Sharing Ith other People Network. . The professionals were interviewed and requested to suggest other potential respondents. This method helped to reduce researcher's bias in selecting respondents because the researcher had no control of who will be invited; hence minimising biasness.

\section{Data Capturing Procedures}

In this study, ICT experts as well as ordinary users were interviewed. The respondents were from the government, private sector, Tanzanians in Diaspora, Non-Governmental Organizations (NGOs) and the United Nations (UN) office in Dar es Salaam (Table 1). Interviews were arranged to take place at respondents' most convenient locations, while those in distant places (e.g. in the diasporas) were contacted by various ICT means (e.g. phone or skype). The paper used semi-structured interview guides to facilitate the flow of the interviews. All interviews were recorded except when respondents felt uncomfortable. The researcher conducted 29 interviews, and each had an average duration of 80 minutes.

Table 1: Interview Respondent Profile

\begin{tabular}{|l|l|}
\hline Category & Number \\
\hline Government & 13 \\
\hline Private Sector & 6 \\
\hline Diaspora & 5 \\
\hline NGOs & 3 \\
\hline UN & 2 \\
\hline Total & $\mathbf{2 9}$ \\
\hline
\end{tabular}

Three main workshops were conducted with participants from the government, private sector, academia, United Nations and NGOs (Table 2). Additionally, there was organised one focus group discussion with respondents from the Tanzania Commission for Science and Technology (COSTECH). At the beginning of each workshop and discussion session, the researcher provided an introductory presentation to familiarise the participants with the research topic, aims and the information they were expected to contribute. The participants were divided into smaller discussion groups, and given them 40 to 60 minutes for discussion. Each group was given a guide to facilitate the discussion. Later, a joint group discussion was convened whereby groups presented their findings. This approach proved useful because it facilitated active participation, probing and clarification of unclear concepts. 
Table 2: Workshop Participants Profile

\begin{tabular}{|l|l|}
\hline Category & Number \\
\hline Government & 9 \\
\hline Private Sector & 14 \\
\hline Academia & 10 \\
\hline UN & 3 \\
\hline NGOs & 4 \\
\hline Total & 40 \\
\hline
\end{tabular}

\section{Data Analysis and Presentation}

This paper has followed the Straus and Corbin's (1990) framework of data analysis. The process was facilitated by means of qualitative data analysis software, Atlas.ti. The software was used to manage data, code, analyse and relate the emerging themes.

The results are linked to data through codes, quotes, and/or field notes. Appendix I and II presents the codes and selected quotes respectively. The researcher makes reference to codes where $F$ and $C$ letters denote facilitator and challenge respectively. Reference is made to quotes, but the confidentiality of the interview respondents is maintained. Therefore, the respondent is denoted in each quote as R.Y where $\mathrm{R}$ stands for respondent and $\mathrm{Y}$ for the number assigned to a particular respondent (e.g. R.5 represents respondent number 5). Likewise, quotes are denoted as $Q X$ where $Q$ means quote and $X$ is quote number.

\section{Findings}

In this study, the researcher was able to identify various issues potential to facilitate and challenge successful implementation of ICT4D in Tanzania as detailed below.

\section{Facilitators of ICT4D}

This paper identifies four issues with a potential to facilitate the implementation of ICT4D in Tanzania. They are (1) affordability of ICTs; (2) availability and adoption of technologies; (3) supportive social infrastructure (levels of literacy and Kiswahili as a homogenous national language); and (4) presence of government commitment.

\section{Affordability of ICTs}

The researcher deduced that the current level of affordability of ICT equipment is one of the key facilitators of ICT4D in Tanzania (Table 3). This issue was prompted by the fact that the government removed the Value Added Tax (VAT) on computers in July 2000 (Miller et al., 2004). VAT on other ICTs was $20 \%$ until July 2009 when the government reduced it to $18 \%$ (UTR, 2009). As a result, the cost of computers decreased, which facilitated the uptake of ICT in the country. This is especially evident in urban areas where the number of internet access points (e.g. cybercafés) and the ownership of personal computers have increased significantly. Second-hand computers can be bought with a price of TSh. ${ }^{1}$ 150,000 (about USD 150). The availability of low cost mobile phones, with a basic model from as little as TSh. 20,000 (about USD 20) has also resulted in widespread penetration. Such prices allow middle-income people, particularly in urban areas, to own a computer at home and a mobile phone. However, it is still expensive for the poor based in rural areas, and low-income people in the urban areas.

\footnotetext{
${ }^{1}$ Tanzanian Shillings
} 
Table 3: Affordability of ICTs

\begin{tabular}{|l|l|l|l|}
\hline Category & Codes & Quote & Observation \\
\hline Affordability of ICT & F1-8 & Q1 & $\begin{array}{l}\text { Prices of ICTs are falling. This makes it possible } \\
\text { for more people to buy and own ICTs } \\
\text { particularly Radio, TVs and mobile phones }\end{array}$ \\
\hline
\end{tabular}

\section{Availability of Domesticable Technologies}

This category relates to technologies with high domestication potential. This is termed as 'Domesticable Technologies' (Table 4). They are such technologies which ordinary households can acquire and own for domestic use.

Table 4: Affordability of ICTs

\begin{tabular}{|l|l|l|l|}
\hline Category & Codes & Quote & Observation \\
\hline $\begin{array}{l}\text { Domesticable } \\
\text { Technologies }\end{array}$ & F9-12 & Q2 & $\begin{array}{l}\text { Availability of domesticable technologies provides } \\
\text { people with available ICT infrastructure within their } \\
\text { reach. Technologies are such as radio, TV and mobile } \\
\text { phones. People are able to domesticate such } \\
\text { technologies and access information. }\end{array}$ \\
\hline
\end{tabular}

Indicators that point to these issues include the availability of technologies, such as TVs, radio and mobile phones are widely available in Tanzania (TCRA, 2009). Many citizens have demonstrated that they are willing to adopt new technologies as seen in the sharp increase of mobile phones between 2000 and 2008 (Table 5). Also noticed is the increase of TVs, and radios in rural areas. The researcher observed that the availability of such technologies provide an infrastructure that if used innovatively, can advance the implementation of ICT4D in the country.

Table 5: Voice Telecommunication Subscribers by Providers (2000 - 2009)

\begin{tabular}{|c|c|c|c|c|c|c|c|c|c|}
\hline \multirow{2}{*}{ YEAR } & \multicolumn{9}{|c|}{ Provider } \\
\cline { 2 - 10 } & BENSON & CELTEL & TIGO & $\begin{array}{c}\text { TTCL } \\
\text { Fixed }\end{array}$ & $\begin{array}{c}\text { TTCL } \\
\text { MOBILE }\end{array}$ & VODACOM & $\begin{array}{c}\text { ZANTEL } \\
\text { MOBILE }\end{array}$ & $\begin{array}{c}\text { ZANTEL } \\
\text { Fixed }\end{array}$ & \begin{tabular}{c} 
TOTAL \\
\hline 2000
\end{tabular} \\
\hline 2001 & - & - & 56511 & 173591 & - & 50000 & 4007 & - & 284109 \\
\hline 2002 & - & 120089 & 160000 & 161590 & - & 300000 & 26770 & - & 768449 \\
\hline 2003 & - & 320000 & 210000 & 147006 & - & 700000 & 68000 & - & 1445006 \\
\hline 2004 & - & 504000 & 303000 & 148360 & - & 1050000 & 85000 & - & 2090360 \\
\hline 2005 & - & 882693 & 422500 & 154420 & - & 1562435 & 96109 & - & 3118157 \\
\hline 2006 & - & 1516832 & 760874 & 150897 & 6390 & 2975580 & 355246 & 747 & 5766566 \\
\hline 2007 & 3300 & 2505546 & 1191678 & 157816 & 72729 & 3870843 & 678761 & 5453 & 8486126 \\
\hline 2008 & 3000 & 3862371 & 2569527 & 116265 & 105804 & 5408439 & 1057652 & 7544 & 13130602 \\
\hline 2009 & 3101 & 4910359 & 4178089 & 157321 & 115681 & 6883661 & 1378595 & 15601 & 17642408 \\
\hline
\end{tabular}




\section{Supportive Social Infrastructure: Literacy and Language}

Although illiteracy is still a challenge to Tanzania, $64 \%$ of the adult population can read and write (CIA, 2009) and most can read, speak and write Kiswahili (Table 6). The existence of one national language has contributed to political and economical stability (Mukuthuria, 2006). If adequately exploited, the use of ICTs and content development and advocacy in Kiswahili could reach a wider audience who could benefit from the utilization of ICT in their social activities. This is particularly so in the development of local electronic services and digital contents.

Table 6: Supportive Social Infrastructure: Literacy and Language

\begin{tabular}{|l|l|l|l|}
\hline Category & Codes & Quote & Observation \\
\hline $\begin{array}{l}\text { Supportive Social } \\
\begin{array}{l}\text { Infrastructure: } \\
\text { Literacy and } \\
\text { Language }\end{array}\end{array}$ & F13-14 & Q3 & $\begin{array}{l}\text { Language and literacy are important social } \\
\text { infrastructures relevant for ICT initiatives. They are } \\
\text { particularly useful for the development of local } \\
\text { content development. }\end{array}$ \\
\hline
\end{tabular}

\section{Presence of Government Will}

Several aspects which indicate the presence of government will were observed. These include high-level policies and support, and establishment of coordination and implementation government organs (Table 7).

Table 7: Presence of Government Commitment

\begin{tabular}{|l|l|l|l|}
\hline Category & Codes & Quote & Observation \\
\hline $\begin{array}{l}\text { Presence of } \\
\text { government } \\
\text { Commitment }\end{array}$ & F16-24 & Q4 & $\begin{array}{l}\text { The involvement of the president and } \\
\text { establishment of various institutions to further } \\
\text { ICT in the country are key facilitators of ICT in } \\
\text { Tanzania }\end{array}$ \\
\hline
\end{tabular}

An important observation is that several actions by the government indicate the presence of political will and support for ICT. Specific aspects identified include the intent highlighted in all key national policies, presence of ICT coordination frameworks and active involvement of the national top leadership in initiation and support of ICT initiatives. Such issues contribute to creating a supportive environment for the success of ICT initiatives in the country.

\section{Challenges Facing ICT4D in Tanzania}

The researcher identifies four categories of issues potential to challenge the success of ICT4D in Tanzania. They include (1) inadequate connectivity; (2) content (service) issues; (3) organisational issues; and (4) people-related issues. 


\section{Inadequate Connectivity}

Connectivity challenges relate to the difficulties that organisations or individuals encounter when deploying or accessing
ICT-enabled initiatives. The researcher relates this issue to the inadequacy of the ICT networks and other supporting infrastructure in the country (Table 8).

\section{Table 8: Inadequate Connectivity}

\begin{tabular}{|l|l|l|l|}
\hline Category & Codes & Quote & Observation \\
\hline $\begin{array}{l}\text { Inadequate } \\
\text { connectivity }\end{array}$ & C1-6 & Q5 & $\begin{array}{l}\text { Although there is a significant availability of } \\
\text { telecommunication services, radio, TV and phones, } \\
\text { rural areas still do not have access to such } \\
\text { technologies. Roads, electricity and other supporting } \\
\text { infrastructure need to also be improved for better } \\
\text { access. }\end{array}$ \\
\hline
\end{tabular}

Typical examples of this issue include the inadequate availability and spread of broadband, lack of electricity and even limited coverage of mobile phone networks (Table 9). ICT equipment, especially computers, is still not widely available, particularly in the rural areas. This impedes the possibility of stimulating demand and deployment of ICT4D initiatives across the country.

Table 9: Tanzania Infrastructure Index, 2008

\begin{tabular}{|l|l|}
\hline Element & Value \\
\hline Internet per 100 users & 1.00 \\
\hline PC per 100 users & 0.93 \\
\hline Cellular subscribers per 100 users & 14.78 \\
\hline Main telephone lines per 100 & 0.40 \\
\hline Users broadband per 100 users & $\ldots$ \\
\hline E-readiness index & 0.2929 \\
\hline Regional average e-readiness index ${ }^{2}$ & 0.2879 \\
\hline World average e-readiness index & 0.4514 \\
\hline World leader e-readiness index & 0.9157 \\
\hline
\end{tabular}

Source: Source: UN, 2008 


\section{Content Quality}

The quality and quantity of the existing ICT enabled services are yet to meet user expectations (Table 10). For instance, much of the content, except news websites and blogs, is infrequently updated and also is not local. Specific examples include the obsolescence of links and tender information on government websites. These elements are often left unattended even when they are no longer useful.

Table 10: Content Quality

\begin{tabular}{|l|l|l|l|}
\hline Category & Codes & Quote & Observation \\
\hline Content Quality & C7-2 & Q6 & $\begin{array}{l}\text { The presence of poor quality digital content is a key } \\
\text { problem. The majority can't comprehend English but } \\
\text { also unavailability of value added services do not } \\
\text { encourage people to use the content. }\end{array}$ \\
\hline
\end{tabular}

Other possible content quality issues include insufficiency and fragmentation of the provided services or information. Additionally, most of the websites, including government websites, are written in English. While English is the official language, most ordinary Tanzanians speak Kiswahili. Consequently, the available content is not perceived to be local. Other service-related issues include lack of responsiveness, incompleteness, lack reliability and dependability.

\section{Organisational Challenges}

Organisational challenges refer to the characteristics or issues which determine the aggressiveness and progress of an organisation towards ICT initiatives. Issues related to this category are the lack of leadership, organisational inertia, inadequate planning and unsupportive processes (Table 11).

Table 11: Content Quality

\begin{tabular}{|l|l|l|l|}
\hline Category & Codes & Quote & Observation \\
\hline $\begin{array}{l}\text { Organisational } \\
\text { Challenges }\end{array}$ & C13-20 & Q7, 8 & $\begin{array}{l}\text { Internal organisational issues hinder innovation, } \\
\text { streamlining and adoption of ICT. Issues such as } \\
\text { planning, policies, laws and business processes need } \\
\text { to be addressed. However, strong leadership is } \\
\text { required to champion the addressing in favour of ICT. }\end{array}$ \\
\hline
\end{tabular}

It is observed that projects with strong leadership conviction and commitment were successful (e.g. the Sengerema community centre project). Other projects stagnated when committed leadership ceased (e.g. the Kilosa community centre project). Equally, inadequate planning; unsupportive policies, practices and processes; and organisational inertia affect the application of ICT in development activities. These issues have also been observed by other researchers (e.g. Mutagahywa et al., 2007). For example, inadequate planning has led to lack of implementation of the National ICT Policy (URT, 2003). Consequently, no responsibility was assigned to any government body. The policy remains a legacy document with minimal interpretation and implementation. The situation is similar at sectoral levels with exception of the Ministry of Education and Vocational Training (URT, 2007). The researcher could not identify other sectoral strategies available on how the national ICT policy will be implemented.

\section{People-Related Issues}

Three people-related issues describes as important for the application of ICT4D; namely, adequacy of ICT skills, ICT awareness and mindset (Table 12). Although various initiatives are being 
deployed in Tanzania, many citizens, especially in the rural areas, do not have adequate skills and awareness to operate ICT equipment, especially computers.
Equally, organisations including the government do not have sufficient skilled people to drive the application of ICT in development initiatives.

Table 12: People-Related Issues

\begin{tabular}{|l|l|l|l|}
\hline Category & Codes & Quote & Observation \\
\hline $\begin{array}{l}\text { People- related } \\
\text { Issues }\end{array}$ & $\mathrm{C} 21-27$ & $\mathrm{Q} 9,10$ & $\begin{array}{l}\text { It is imperative that ICT awareness and skills and } \\
\text { mindset are enhanced in Tanzania. Alternatively, ICT } \\
\text { Initiatives need to be developed to accommodate the } \\
\text { current situation. This will also need to reflect the } \\
\text { financial affordance of the people, especially in the rural } \\
\text { areas. }\end{array}$ \\
\hline
\end{tabular}

The third issue relates to unsupportive mindsets particularly among the older generation presently in decision-making positions. This may have a historical reason as the Government of Tanzania banned the use and importation of ICT (e.g. TVs, computers) in the early 1970 s. As a result, the ownership and use of these technologies was perceived to be illegal and a luxury. The long-term effect has been that decision makers lack the power to conceptualise and exploit the potential of ICT in development. This culminates in a limited number of ICT initiatives, limited utilisation of ICTs in development initiatives, inadequate support, prioritisation and advocacy of ICT from the policy, implementation and use levels.

\section{Discussion}

In this study, the researcher aims at establishing issues potential to facilitate or challenge successful implementation of ICT4D in Tanzania. The paper established that possible facilitators include affordability of ICTs, availability of domesticable technologies, presence of supportive social infrastructure and presence of government will. On the other hand, issues potential to challenge the implementation of ICT4D in Tanzania are inadequacies in connectivity, content quality, organisational issues and peoplerelated issues.

\section{Facilitators of ICT4D}

The results of this study are supported by the literature. For instance, various studies have been undertaken on issues related to the importance of affordability of ICTs (e.g. Cawley \& Hynes, 2010; UN, 2012); affordability availability of domesticable technologies (NAO, 2002); literacy and language (Fourie, I. Krauss, 2011; Henson, 2005), government will and support (Venkatesh et al., 2003). However, in most cases, they are presented from a challenge perspective. In the present case, it was found that although they may be inadequate, their presence facilitates ICT4D. Further, innovative advancement and exploitation of such factors may contribute to the success of ICT4D. Accordingly, the government and other ICT stakeholders of Tanzania need to embrace this perspective for the advancement and success of ICT initiatives in the country.

\section{Challenges of ICT4D}

Issues related to adequacy of connectivity have been widely discussed (e.g. EOCD, 2007; InfoDev, 2002; UN, 2008, 2005). These issues are expected especially in a developing country context. Inadequate access infrastructure is currently challenging the advancement of ICT initiatives for development in Tanzania. It is therefore necessary that access infrastructure is enhanced to facilitate the streaming into development activities. In the Tanzanian context, this can be achieved through innovative use of existing access infrastructure such as mobile phones, TV and radio. In this way, ICT initiatives will extend and reach more people especially in the rural areas. 
Studies that relate to the value of content in ICT initiatives exist (e.g. Kumar et al., 2007; Tan, Benbasat, \& Cenfetelli, 2008). It has been argued that poor quality of the content may greatly contribute to failure of ICT-related initiatives. This was also the case in Tanzania. A particular quality aspect is the use of foreign language to present local content. Adoption of bilingual strategy could be useful to address this issue (UN, 2012).

Organisational issues have also received the attention of researchers (e.g. Ho \& Ni, 2004; Mgaya, 1999). Organisational issues such as poor championship, unsupportive business processes and legal framework are common in the developing countries context. Possible strategies relevant to addressing such issues may include the integration of monitoring and evaluation, and awareness raising mechanisms in all stages of ICT initiatives (Wagner et al., 2005).

Various authors have provided insights similar to the people-related issues (Diminitrova \& Chen, 2006; Ebrahim \& Irani, 2005; Gupta et al., 2008; Ho \& Ni, 2004; Venkatesh, 2003; Warkentin et al., 2002). It has been suggested that inadequacies in user characteristic particularly the awareness, ability to operate ICT equipment and mindset may impede the implementation of ICT4D. Accordingly, governments and other stakeholders need to devise mechanisms to mitigate or address such issues. Strategies such as education and awareness campaigns may be useful in addressing such issues (Yonazi, 2010).

\section{Suggested View of Facilitators and Challenges of ICT4D in Tanzania}

The facilitators and challenges identified in this study offer a new understanding of implementing ICT4D in Tanzania. Consequently, the researcher observes that when a current challenge is adequately addressed, it may turn into a facilitator. Likewise, ignoring the current facilitator may create a future challenge for ICT4D. For instance, addressing the current adequacy of content may turn into a facilitator. Similarly, ignoring the potential of the existing social infrastructure may create a challenge to the accessing and adoption of ICT4D initiatives.

The above view is depicted in Figure 2. The figure shows the current challenges of ICT4D in the low side of the continuum of adequacy and facilitators to the high side. Addressing a challenge may result in moving it towards the high adequacy side, while ignoring a facilitator may shift it towards the low-side of the continuum. Accordingly, efforts should be made to address challenges, exploit and advance facilitators and maintain them on the high side of the continuum of adequacy.

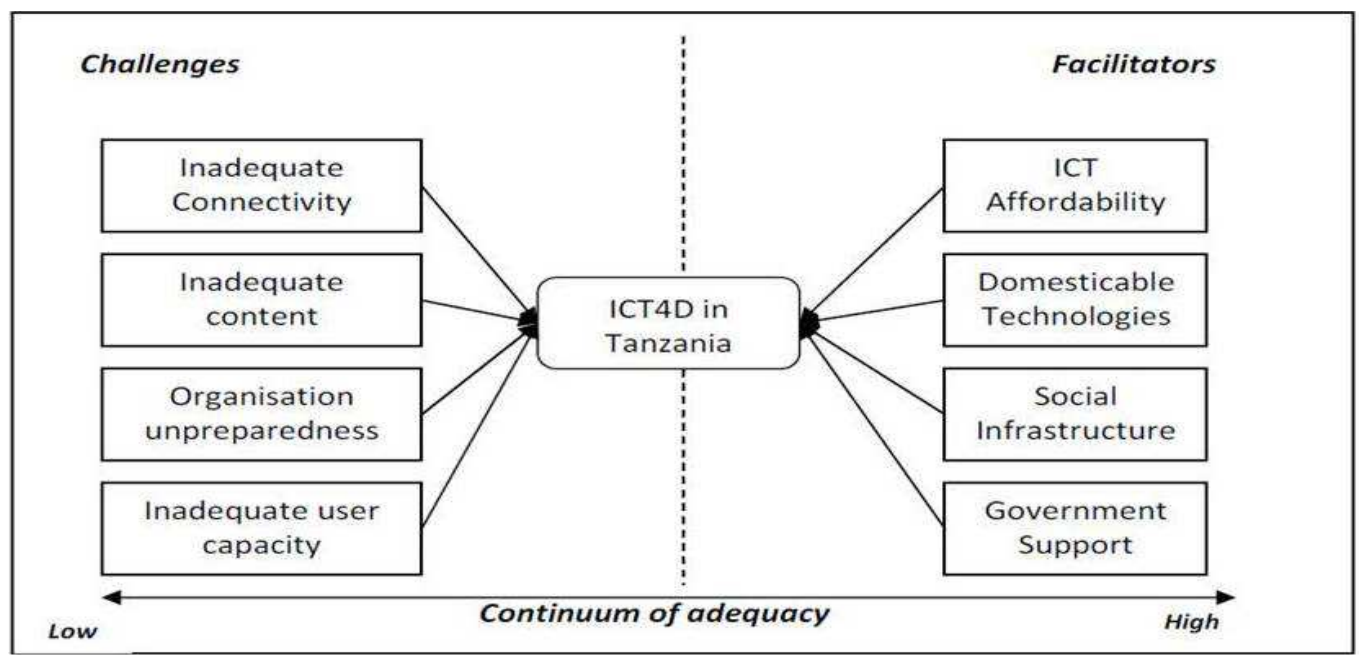

Figure 1: Facilitators and Challenges of ICT4D in Tanzania (Source: Own Conceptualisation) 


\section{Conclusion}

In this study, the researcher identifies issues that will likely facilitate and challenge ICT4D in Tanzania. The researcher argues that it is important to understand and exploit the facilitators, while addressing the challenges in favor of ICT4D. The paper therefore introduces a new view regarding the position of challenges and facilitators of ICT4D in Tanzania. It is concluded that it is possible to successfully implement ICT4D in Tanzania through addressing challenges and exploiting facilitators. These results may be useful to ICT4D initiatives in Tanzania. However, they may be applicable in the contexts of other similar developing countries. Accordingly, improvements such as prioritisation of issues and customization need to be considered.

\section{References}

Cawley, A. \& Hynes, D. (2010). "Evolving Mobile Communication Practices of Irish Teenagers," Aslib Proceedings, Vol. 62 (1), pp. $29-45$.

CIA. (2006). "The World Fact Book: Tanzania," CIA. Retrieved November, 21, 2006, from https://www.cia.gov/library/publications/ the-world-factbook/geos/tz.html

CIA. (2009). "The World Fact Book: Tanzania," CIA. Retrieved February 14th 2009, from https://www.cia.gov/library/publications / the-world-factbook/geos/tz.html

Cole, R. D. \& Roman, R. (2003). "ICT4D: A Frontier for Higher Education in Developing Nations," Journal of Africa and Asia Studies, 2, 381 - 420.

Dimitrova, D. V. \& Chen, Y. (2006). "Profiling the Adopters of e-Government Information Services: The Influence of Psychological Characteristics, Civic Mindedness, and Information Channels," Social Science Computer Review, 24 (2), 172-188.
Ebrahim, Z. \& Irani, Z. (2005). "eGovernment Adoption: Architecture and Barriers," Business Process Management Journal, 11 (5), 589 -611.

Fourie, I. \& Krauss, K. (2011). "Information Literacy Training for Teachers in Rural South Africa," Journal of Systems and Information Technology, Vol. 13 (3), Pp.303 $-321$.

Gupta, B., Dasgupta, S. \& Gupta, A. (2008). "Adoption of ICT in a Government Organization in a Developing Country: An Empirical Study," The Journal of Strategic Information Systems, 17, (2), 140-154.

Hamelink, C. J. (1997). New Information and Communication Technologies, Social Development and Cultural Change. Accessed on: 12th Feb, 2009, From: http://www.unrisd.org/80256B3C005BCC F9/(httpAuxPages)/398D6A86112708478 0256B640051A497/\$file/dp86.pdf

Heeks, R. (2005). "e-Government as a Carrier of Context," Journal of Public Policy, 25, 51-74, Cambridge University Press.

Henson, J. M. (2005). "Factors That Inhibit Economic Development in the Information and Communications Technology Industry at the Regional Level," Management Decision, Vol. 43 (3) Pp. 317 - 330.

Ho, A. T. K. \& Ni, A. Y. (2004). "Explaining the Adoption of e-Government Features: A Case Study of Iowa Country Treasures' Offices," American Review of Public Administration, 34 (2) 164-180.

IICD. (2008). "IICD Supported Programme: Telemedicine - Tanzania," IICD. Accessed, 12th Feb, 2009, from: http://www.iicd.org/projects/tanzaniatelemedicine

InfoDev. (2002). "The e-Government Handbook for Developing Countries: A Project for InfoDev and The Center for Democracy and Technology," Retrieved October 2nd, 2005 from http://unpan1.un.org/intradoc/groups/pu blic/documents/apcity/unpan007462.pdf 
ITU. (2007). Telecommunication/ICT Market and Trends in Africa, Geneva, Switzerland.

Kramer, W. J., Jenkins, B. \& Kats, R. S. (2007). The Role of the Information and Communication Technology Sector in Expanding Economic Opportunity. Corporate Social Responsibility Initiative Report No. 2. Cambridge MA, Kennedy Schools of Government, Harvard University.

Kumar, V., Murkerji, B., Butt, I. \& Persaud, A. (2007). "Factors for Successful EGovernment Adoption: A Conceptual Framework," The Electronic Journal of $e$ Government, 5 (1), 63 - 76.

Mgaya, R. J. S. (1999). Adoption and Diffusion of Group Support Systems in Tanzania. Phd Thesis, Delft University of Technology, The Netherlands.

Miller, J., Kartano, K. \& Ntiro, S. (2004). "ICT Investment Opportunities in East Africa: Country Specific Market Analysis Tanzania," International Finance Corporation. Accessed November 20, 2006, from

www.trigrammic.com/downloads/new200 5/Tanzania\%20Report.pdf

Mukuthuria, M. (2006). "Kiswahili and Its Expanding Roles of Development in East African Cooperation: A Case of Uganda," Nordic Journal of African Studies, 15 (2), 154-165.

Mutagayhwa, B., Kinyeki, C. \& Ulanga, J. (2007). 'A Review of E-Government Related Interventions in PSRP Phase I and Advice on a Strategy Framework towards PSRP Phase II,' POPSM, Dar Es Salaam, Tanzania.

NAO. (2002). Better Public Services through e-Government, Academic Article in Support of Better Public Service through eGovernment. London: House of Commons.

OECD. (2007). OECD E-Government Studies: Turkey 2007. Paris: OEDC Publishing France.

Peansupap, V. \& Walker, D. H. T. (2006). "Information Communication Technology
(ICT) Implementation Constraints: A Construction Industry Perspective," Engineering, Construction and Architectural Management, Vol. 13 (4). pp. 364 - 379.

Sawe, D. (2007). 'Serikali Mtandao; Madhumuni, Matatizo, Mafanikio, Na Changamoto,' POPSM, Dar Es Salaam, Tanzania.

Straus, A. \& Corbin, J. (1990). 'Basics of Qualitative Research: Grounded Theory Procedures and Techniques,' SAGE Publications, USA.

Tan, C. W., Benbasat, I. \& Cenfetelli, R. T. (2008). Building Citizen Trust Towards eGovernment Services: Do High Quality Websites Matter? Proceedings of the 41st Hawaii International Conference on System Science, IEEE.

UN. (2005). 'Global E-government Readiness Report 2005: From EGovernment to E-Inclusion,' New York: United Nations.

UN. (2008). 'e-Government Survey 2008: From E-Government to Connected Governance,' United Nations, New York.

UN. (2010). Information Economy Report 2010. UNCTAD, GENEVA, Switzerland.

UN. (2012). e-Government Survey 2012: eGovernment for the People. New York: United Nations.

URT. (1998). 'National Poverty Eradication Strategy,' UTR, Dar Es Salaam, Tanzania.

URT. (2000). 'National Poverty Reduction Strategy,' UTR, Dar Es Salaam, Tanzania.

URT. (2003). National ICT Policy. URT, Dar es Salaam, Tanzania.

URT. (2005). National Strategy for Growth and Reduction of Poverty. URT, Dar es Salaam, Tanzania.

URT. (2006). 'Universal Communications Service Act.' Available at: http://www.parliament.go.tz/bunge/act.p hp? search=2006\&imageField. $x=0$ \&imageFi eld. $y=0 \&$ select $2=0$ 
URT. (2007). 'Information and Communication Technology (ICT) Policy for Basic Education,' URT, Dar Es, Salaam, Tanzania.

URT. (2008). Telecommunication Statistics as at 30th September 2008', Tanzania Communications Regulatory Authority. Accessed on 12, January, 2009, from; http://www.tcra.go.tz/publications/teleco m.html

URT. (2009). Hotuba ya Waziri wa Fedha na Uchumi Mhe. Mustafa Haidi Mkulo (MB.), Akiwasilisha Bungeni Mapendekezo ya Serikali Kuhusu Makadirio ya Mapato na Matumizi kwa Mwaka 2009/2010. Accessed on 3rd July, 2009, from: http://www.mof.go.tz/mofdocs/budget/H otuba\%20ya\%20Bajeti\%202009\%208.06. 2009\%20FINAL\%20text.pdf

Venkatesh, V., Morris, M. G., Davis, G. B. \& Davis, F. D. (2003). "User Acceptance of Information Technology: Toward a Unified View," MIS Quarterly, 27 (3), 425-478.

Walsham, G. (1993). Interpreting Information Systems in Organizations. Chichester, Wiley.

Wagner, D. A., Day, B., James, T., Kozma, R. B., Miller, J. \& Unwin, T. (2005). Monitoring and Evaluation of ICT in Education Projects. A Handbook for Developing Countries. Washington DC: infoDev. Accessed 17 September: 2009 from http://www.infodev.org/files/2942_file_M _E_ICT_Education_draft_WSIS_optimized.pd

Warkentin, M., Gefen, D., Pavlou, P. A. \& Rose, G. M. (2002). "Encouraging Citizen Adoption of e-Governent by Building Trust," Electronic Markets, 12 (3), 57-162.

Yonah, Z. (2005). ICTs as Tools for Poverty Reduction. Proceeding of the Discourse on Engineering Contribution in Poverty Reduction.

Yonazi, J. J. (2010). Enhancing Adoption of e-Government Initiatives in Tanzania. PhD Thesis. University of Groningen, The Netherlands.
Yusoff, A. Y. \& Lim, S. Y. P. (2003). 'Understanding ICT4D Thematics in Malaysia: A Sourcebook,' UNDP. 
Appendix I: Coding of the Key Categories

\begin{tabular}{|c|c|c|c|}
\hline Code No. & Open coding & Axial Coding & Focused Coding \\
\hline F1 & Cheapness of technology & \multirow{6}{*}{ Tax relief } & \multirow{8}{*}{ Affordability of ICTs } \\
\hline F2 & Tax relief & & \\
\hline F3 & No tax on computers & & \\
\hline F4 & Affordable because now & & \\
\hline F5 & Chinese phones & & \\
\hline F6 & People have phones & & \\
\hline F7 & High adoption rate & \multirow{2}{*}{ High adoption rate } & \\
\hline F8 & Everyone had a phone (adoption high) & & \\
\hline F9 & Televisions are available & \multirow{3}{*}{$\begin{array}{l}\text { Availability of } \\
\text { Technologies }\end{array}$} & \multirow{4}{*}{$\begin{array}{l}\text { Availability of Technologies } \\
\text { with High Domestication } \\
\text { Potential }\end{array}$} \\
\hline F10 & Radios are available & & \\
\hline F11 & Having a Phone & & \\
\hline F12 & Technology-need fit & Domestication & \\
\hline F13 & Know Kiswahili & \multirow{2}{*}{ Language homogeneity } & \multirow{2}{*}{$\begin{array}{l}\text { Supportive social } \\
\text { infrastructure }\end{array}$} \\
\hline F14 & One language Kiswahili & & \\
\hline F15 & Education and Literacy level at 65\% & Literacy level & \\
\hline F16 & Coordinating ministry & \multirow{4}{*}{ Coordination mechanism } & \multirow{9}{*}{$\begin{array}{l}\text { Presence of government } \\
\text { will }\end{array}$} \\
\hline F17 & Tanzania Regulatory authority & & \\
\hline F18 & Universal Access Fund & & \\
\hline F19 & Commission for Science and Technology & & \\
\hline F20 & Minister is in this & \multirow{5}{*}{ Top Government support } & \\
\hline F21 & National fibre project ongoing & & \\
\hline F22 & $\begin{array}{l}\text { Mkukuta, ICT Policy, } 2003+\text { Other } \\
\text { policies }\end{array}$ & & \\
\hline F23 & Microsoft MoU & & \\
\hline F24 & $\begin{array}{l}\text { President support, top leadership } \\
\text { support }\end{array}$ & & \\
\hline $\mathrm{C} 1$ & Farmers can't use & Inadequate connectivity & \multirow{6}{*}{ Poor Connectivity } \\
\hline $\mathrm{C} 2$ & No service for agriculture & \multirow{3}{*}{ Poor network coverage } & \\
\hline $\mathrm{C} 3$ & No Network in villages & & \\
\hline $\mathrm{C} 4$ & VODACOM Is not available here & & \\
\hline $\mathrm{C} 5$ & Equipment unavailability in the rural & \multirow{2}{*}{ Unavailability of ICTs } & \\
\hline $\mathrm{C} 6$ & Not everyone has a phone & & \\
\hline C7 & There isn't much for me & \multirow{2}{*}{ Service inadequacy } & \multirow{6}{*}{ Inadequate Content Quality } \\
\hline $\mathrm{C} 8$ & Local content & & \\
\hline C9 & No Swahili information & \multirow{2}{*}{$\begin{array}{l}\text { Local Information } \\
\text { customisation }\end{array}$} & \\
\hline $\mathrm{C} 10$ & No updates & & \\
\hline $\mathrm{C} 11$ & No information for agriculture & \multirow{2}{*}{ Information coverage } & \\
\hline C12 & Updating information & & \\
\hline $\mathrm{C} 13$ & Organisation inertia & \multirow{5}{*}{ Inadequate processes } & \multirow{8}{*}{ Organisational challenges } \\
\hline C14 & Procurement processes are hard & & \\
\hline $\mathrm{C} 15$ & No law for ICT & & \\
\hline C16 & No ICT Strategy & & \\
\hline $\mathrm{C} 17$ & Poor planning & & \\
\hline C18 & Resistance to change & \multirow{3}{*}{ Inadequate leadership } & \\
\hline C19 & Where is the champion? & & \\
\hline $\mathrm{C} 20$ & The leader left & & \\
\hline $\mathrm{C} 21$ & Mindset & \multirow{2}{*}{ Mindset } & \\
\hline $\mathrm{C} 22$ & Need to see a real person on a computer & & \\
\hline $\mathrm{C} 23$ & Can't speak English & Need for Kiswahili & \\
\hline $\mathrm{C} 24$ & Can't afford a computer & Financial Affordance & People-related Issues \\
\hline $\mathrm{C} 25$ & Not my area of expertise & & \\
\hline $\mathrm{C} 26$ & No awareness & ICT Skills and awareness & \\
\hline $\mathrm{C} 27$ & ICT literacy & & \\
\hline
\end{tabular}


Appendix II: Sample Quotes

\begin{tabular}{|c|c|}
\hline Quote no & Imple Quote \\
\hline $\mathrm{Q} 1$ & $\begin{array}{l}\text { "I recall there were hardly any cybercafés back in June } 2000 \text { which is when the tax on } \\
\text { computers was lifted. It was an ethinkTankTZ initiative during our first year of existence. } \\
\text { We sent a small delegation to meet the Minister of Finance around April or so that year. } \\
\text { We prepared a paper describing the advantages of increasing the penetration of IT as } \\
\text { opposed to targeting IT for Taxation. The boom of cybercafés is one of the advantages of } \\
\text { the VAT relief on computers." R.1. }\end{array}$ \\
\hline Q2 & $\begin{array}{l}\text { "Advancement in technologies is a facilitating factor. People have been fast in adopting } \\
\text { technologies. For instance, currently we have more than } 10 \text { million mobile phone } \\
\text { subscribers. Many people including secondary school pupils have and use mobile } \\
\text { phones". R2. }\end{array}$ \\
\hline $\mathrm{Q3}$ & $\begin{array}{l}\text { "Tanzania uses one language, it is easy to communicate, advocate and develop contents in } \\
\text { a language that everyone understands. A typical example is the AIDS awareness } \\
\text { campaign. They mainly use Kiswahili. This makes it possible to reach people even in } \\
\text { remote areas. I think it is time that we have to shift from using English in ICT to } \\
\text { localisation through Kiswahili.". R.3. }\end{array}$ \\
\hline $\mathrm{Q} 4$ & $\begin{array}{l}\text { The value of ICT in Strategy for Growth and Reduction of Poverty (2005), National ICT } \\
\text { policy (2003) and other sectoral policies such as the ICT policy for basic education (URT, } \\
\text { 2007). (Recognition of the value of ICT at the national top priority policies and strategies) } \\
\text { Ministry of Universal Communications Services Access Fund, Ministry of } \\
\text { Communications, Science, and Technology, Commission of Science and Technology } \\
\text { (COSTECH), and Tanzania Communications Regulatory Authority (Establishment of ICT } \\
\text { coordination and regulatory machinery). } \\
\text { Memorandum of understanding signed by H.E. Jakaya Mrisho Kikwete, the President of } \\
\text { Tanzania, and the Chairman of Microsoft, Mr. Bill Gates in } 2006 \text { (Involvement of top level } \\
\text { leadership) }\end{array}$ \\
\hline $\mathrm{Q5}$ & $\begin{array}{l}\text { "When you talk about ICT4D I undertand that you are considering people in towns. My } \\
\text { parents in the village can't comprehend your concepts. They only have a radio. They do } \\
\text { not have electricity, and even the phone i provided them with they have to charge using a } \\
\text { car catter. R.11" }\end{array}$ \\
\hline Q6 & $\begin{array}{l}\text { "Yes, our website is in English. It is not necessary that it remains so, but we are just used } \\
\text { to develop websites in English. In the future we will develop a Kiswahili version. But, it is } \\
\text { not our fault because even the minister sometimes gives his speeches in English..".R.9. }\end{array}$ \\
\hline Q7 & $\begin{array}{l}\text { "Leadership is another important challenge. I will also give you an example. The District } \\
\text { Executive Director for Kilosa went to Sengerema and wanted a similar project in her area. } \\
\text { That was done successfully. However, after she was transferred to another area support } \\
\text { problems started. People started calling even the local radio by her name. Madiwani4 } \\
\text { were divided such that diwanis from distant areas where the community radio cannot be } \\
\text { heard did not want to contribute to the sustainability of the radio". R.4. }\end{array}$ \\
\hline Q8 & $\begin{array}{l}\text { "I think many people are yet to be knowledgeable about ICT projects. For this reason they } \\
\text { do not know even how to write good ICT policies. The unsupportive ICT policies that we } \\
\text { have are results of such poor skills." R.5. }\end{array}$ \\
\hline Q9 & $\begin{array}{l}\text { "The perception of people as well as the general public has to change. Tanzania is yet to } \\
\text { grasp the importance of ICT. It is mostly regarded as a luxury rather than an important } \\
\text { developmental tool. Many leaders are not aware of ICT potentials. This makes it difficult } \\
\text { for them to put ICT as one of the priority issues in their activities. As a result ICT } \\
\text { initiatives face some difficult bureaucracies. This is one of the major problems." R.6. }\end{array}$ \\
\hline Q10 & $\begin{array}{l}\text { "I think many people are yet to be knowledgeable about ICT projects. For this reason they } \\
\text { do not know even how to write good ICT policies. The unsupportive ICT policies that we } \\
\text { have are results of such poor skills." R.5. }\end{array}$ \\
\hline
\end{tabular}

${ }^{4}$ Madiwani means local councillors 